\title{
New moss records from the Republic of Tuva
}

\author{
O. Yu. Pisarenko \\ Central Siberian Botanical Garden, SB RAS, Zolotodolinskaya str., 101, Novosibirsk, 630090, Russian Federation. \\ E-mail: o_pisarenko@mail.ru
}

Keywords: Altai-Sayan mountain region, biogeography, mosses, Red Data Book, South Siberia.

Summary. Eight new species for the Republic of Tuva were revealed in the author's herbarium collection: Calliergon richardsonii (Mitt.) Kindb., Coscinodon cribrosus (Hedw.) Spruce, Hymenostylium recurvirostrum (Hedw.) Dixon, Isopterygiopsis pulchella (Hedw.) Iwats., Loeskypnum badium (Hartm.) H. K. G. Paul, Plagiobryum demissum (Hook.) Lindb., Pseudocalliergon turgescens (T. Jensen) Loeske, Tayloria lingulata (Dicks.) Lindb. Herbarium labels are quoted, and the distribution features of the species are discussed. The same for the three species which previously were known in the Republic of Tuva by single specimens - Fissidens osmundoides Hedw., Pseudocalliergon trifarium (F. Weber et D. Mohr) Loeske, Indusiella thianschanica Broth. et Müll. Hal. The last species is in the Red Data Book of the Russian Federation (Dudareva et al., 2008) and also in the Red Data Book of the Republic of Tuva (Pisarenko, Bakalin, 2018).

\section{Новые находки мхов в Республике Тыва}

\author{
О. Ю. Писаренко
}

Центральный сибирский ботанический сад СО РАН, ул. Золотодолинская, 101, г. Новосибирск, 630090, Россия

Ключевые слова: Алтае-Саянская горная область, биогеография, Красная книга, листостебельные мхи, Южная Сибирь.

Аннотация. При обработке собственных гербарных сборов выявлены новые для Республики Тыва виды мхов - Calliergon richardsonii (Mitt.) Kindb., Coscinodon cribrosus (Hedw.) Spruce, Hymenostylium recurvirostrum (Hedw.) Dixon, Isopterygiopsis pulchella (Hedw.) Iwats., Loeskypnum badium (Hartm.) H. K. G. Paul, Plagiobryum demissum (Hook.) Lindb., Pseudocalliergon turgescens (T. Jensen) Loeske, Tayloria lingulata (Dicks.) Lindb. Для них, а также для известных ранее по единичным образцам Fissidens osmundoides Hedw., Indusiella thianschanica Broth. et Müll. Hal., Pseudocalliergon trifarium (F. Weber et D. Mohr) Loeske цитируются гербарные этикетки, обсуждаются особенности распространения приведенных видов. I. thianschanica включен в Красную книгу Российской Федерации (Dudareva et al., 2008), а также в Красную книгу Республики Тыва (Pisarenko, Bakalin, 2018).

\section{Introduction}

The Republic of Tuva is one of the largest republics in Russia. It extends from north to south between $53^{\circ} 43^{\prime} \mathrm{N}$ and $49^{\circ} 47^{\prime} \mathrm{N}$ and borders Mongolia to the South. It is between $88^{\circ} 47^{\prime} \mathrm{E}$ and $99^{\circ} 16^{\prime} \mathrm{E}$ in longitude and borders the Republic of Altai in the West and the Republic of Buryatia in the East. The territory is geomorphologically heterogeneous: vast intermountain basins combine with ridges and plateaus. The highest point is Mongun-Taiga Mts $3976 \mathrm{~m}$ a. s. 1. The Republic of Tuva is characterized by an increased continental climate compared with the adjoining regions of Siberia. South Tuva Mountains are the watershed between the river basin of the Arctic Ocean and the drainless region 
of Central Asia. This watershed is the southern limit for the Siberian taiga landscapes and the northern one for the desert-steppe landscapes of Mongolia. In phytogeography terms, the mountain range of southern Tuva marks the border of the Boreal and ancient Mediterranean floristic sub-kingdoms of the Holarctic (Takhtajan, 1986).

It is surprising, but today the Republic of Tuva is one of the biggest bryological "white spot" of Russia. For this vast and heterogeneous territory, there is the only one list of local bryoflora, for the Todzha Valley (Otnyukova, 2003). Additionally, for some species it is possible to find information about their locations in the territory (Bardunov, 1972, 1974). To fill the gap some keyplots were investigated recently and about 50 species were revealed as new for the territory immediately, among them so interesting as Amblyodon dealbatus (Hedw.) P. Beauv., Catoscopium nigritum (Hedw.) Brid., Tortella spitsbergensis (Bizot et Thér.) O. Werner, Köckinger et Ros and others (Pisarenko, 2013, 2018; Pisarenko, Artemov, 2019); and also species from the Red Data Book of the Russian Federation - Aongstroemia julacea (Hook.) Mitt. (Bardunov, 2008), Hilpertia velenovskyi (Schiffn.) R. H. Zander. (Czernyadjeva et al., 2008). The paper continues the list of new findings.

\section{Materials and methods}

The work is based on the materials of the author collected in 2013 and 2018-2019. The specimens examined are deposited in the Central Siberian Botanical Garden (NSK), duplicates are in the herbariums of the Altai State University (ALTB) and Moscow State University (MW). The location coordinates are determined using a 12-channel GPS and are given in decimal degrees. The names of moss species are mainly according to the "Check-list of mosses of East Europe and North Asia (Ignatov et al., 2006); names of vascular plants are according to the "Check-list of the flora of Asian Russia" (Konspekt flory ..., 2012).

\section{Species new for the Republic of Tuva}

Calliergon richardsonii (Mitt.) Kindb.

Specimens examined: "Russia, the Republic of Tuva, Mongun-Taiga Distr., Chikhacheva Range, $\mathrm{N}$-faced macroslope, Chedi-Tey River headwaters, 2395 m. 50 $13^{\prime} 26.69^{\prime \prime} \mathrm{N}, 8^{\circ} 25^{\prime} 10.78^{\prime \prime} \mathrm{E}$, sedgemoss swamp along the periphery of small lake, in admixture with Scorpidium cossonii (Schimp.)
Hedenäs. 22 VII 2019. O. Pisarenko. NSK2007842" (NSK, ALTB); "Russia, the Republic of Tuva, Mongun-Taiga Distr., near Khindigtik-Khol Lake, 2296 m. $50^{\circ} 23^{\prime} 50.75^{\prime \prime} \mathrm{N}, \quad 89^{\circ} 58^{\prime} 50.2^{\prime \prime} \mathrm{E}$, gentle slightly concave slope, mire community with predominance of Betula rotundifolia Spach, Eriophorum vaginatum L. and Aulacomnium palustre (Hedw.) Schwägr. 2 VIII 2019. O. Pisarenko. NSK2007870" (NSK).

Calliergon richardsonii is obligate swamp species. It is distributed mainly in the arctic and subarctic zones; in the boreal zone it is known from a few localities (Lapshina, 2003; Ignatov, Ignatova, $2004)$; in south it rarely occurs in the mountains from South Europe (Hodgetts, 2015) to Caucasus (Ignatov, Ignatova, 2004) and Mongolia (Tsegmed, 2010). In Altai-Sayan region the species is rare; there are a few records for Altai (Ignatov, 1994), for Khakassia and for the ranges of the West and East Sayan within the Krasnoyarsk Territory and the Irkutsk Province (Bardunov, 1974).

Coscinodon cribrosus (Hedw.) Spruce

Specimens examined: "Russia, the Republic of Tuva, Mongun-Taiga Distr., Kargy River valley downstream of Mugur-Aksy settlement, $1650 \mathrm{~m}$. $50^{\circ} 17^{\prime} 7.8^{\prime \prime} \mathrm{N}, 90^{\circ} 39^{\prime} 29.52^{\prime \prime} \mathrm{E}$, steep $\mathrm{N}$-faced rock outcrops, on stones. 8 VIII 2019. O. Pisarenko. NSK2008043, S+" (NSK, ALTB).

The species prefers xeric habitats and has wide but disjunctive distribution in the Holarctic. In Russia it is known from scattered localities from Kola Peninsula to South Kuril Islands by way of the Caucasus, Transbaikalia, Yakutia and Kamchatka (Ignatov et al., 2017; Herbarium specimens of Russian mosses, URL: http://arctoa.ru/Flora/basa. php). The species is distributed in many regions of Mongolia (Tsegmed, 2010), but in Altai-Sayan region it was reported only from Altai Mts (Ignatov, 1994).

Hymenostylium recurvirostrum (Hedw.) Dixon Specimens examined: "Russia, the Republic of Tuva, Erzin Distr., Sangilen highlands, the upper reaches of the Naryn river, 1913 m. 50 $13^{\prime} 31.94^{\prime \prime} \mathrm{N}$, $96^{\circ} 16^{\prime} 56.86^{\prime \prime} \mathrm{E}$, limestone outcrops in a shallow gully. 12 VII 2013. O. Pisarenko. NSK2007134" (NSK, ALTB); "Russia, the Republic of Tuva, Erzin Distr., Sangilen highlands, the upper reaches of the Balyktyg-Khem river, $2230 \mathrm{~m} .50^{\circ} 18^{\prime} 56.52^{\prime \prime} \mathrm{N}$, $96^{\circ} 27^{\prime} 44.28^{\prime \prime} \mathrm{E}$, foot of $\mathrm{N}$-faced slope, on stones in Betula rotundifolia Spach thickets. 17 VII 2013. O. Pisarenko. NSK2007135" (NSK). 
The species is widely distributed in most areas of the Holarctic. It occurs mainly in the mountains and grows on wet rocks, more often on limestone. In Siberia it reaches the high Arctic: is known from the Taimyr Peninsula, from the Yakut Arctic, and from the Novosibirsk Islands. But it is more common in the mountains of the southern part of the territory in the Altai, in the Sayan, in the Baikal region (Herbarium specimens of Russian mosses. URL: http://arctoa.ru/Flora/basa.php). It is not rare in Mongolia (Tsegmed, 2010).

Isopterygiopsis pulchella (Hedw.) Iwats.

Specimens examined: "Russia, the Republic of Tuva, Erzin Distr., Sangilen highlands, Naryn river valleyvicinity, Naryn settlement, $1320 \mathrm{~m}$. $50^{\circ} 12^{\prime} 7.85^{\prime \prime} \mathrm{N}, 95^{\circ} 36^{\prime} 19.44^{\prime \prime} \mathrm{E}$, floodplain forest from Picea obovata Ledeb., on rotten log. 06 VII 2013. O. Pisarenko. NSK2007530" (NSK, ALTB); "Russia, the Republic of Tuva, Bay-Tayga Distr., Kara-Khol Lake surroundings, N-faced slope, 1900 m. $51^{\circ} 20^{\prime} 47.68^{\prime \prime} \mathrm{N}, 89^{\circ} 25^{\prime} 15.71^{\prime \prime} \mathrm{E}$, larchforest, on rotten log. 10 VII 2018. O. Pisarenko. NSK2007362" (NSK).

The species takes place in most regions of the Holarctic. It is more common in regions with cold and cool climates; it is widely distributed from the tundra zone to coniferous and broad-leaved forests and in mountains. It grows on rotten log in forests and in breaks of grass turf on the soil in tundra, in crevices of rock outcrops and in niches of stone fields. It is rare or absent in arid areas. In Siberia, it occurs from the high Arctic to the Altai and Sayan and is more common in mountainous regions. In Mongolian mountains it is also not rare (Tsegmed, 2010).

Loeskypnum badium (Hartm.) H. K. G. Paul Specimens examined: "Russia, the Republic of Tuva, Bay-Tayga Distr., Kara-Khol` Lake vicinity, Caste-Khol Lake shore, 1930 m. $51^{\circ} 26^{\prime} 35.3^{\prime \prime} \mathrm{N}$, $89^{\circ} 23^{\prime} 45.31^{\prime \prime} \mathrm{E}$, wet community with Betula rotundifolia predominance, in moss cover, a mixture with Warnstorfia sarmentosa (Wahlenb.) Hedenäs. 11 VII 2018. O. Pisarenko. NSK2007374" (NSK, ALTB).

The species is widespread mainly in the Arctic and subarctic regions; to the South it occurs sporadically in the high mountains. It grows in mineralotrophic mires and in wet tundra. In South Siberia it is rather rare, known from a few localities in southeast Altai and in East Sayan (Herbarium specimens of Russian mosses. URL: http://arctoa.ru/Flora/ basa.php). In Mongolia for the species there is the only record from the last century (Abramova, Tsegmed 1983).

Plagiobryum demissum (Hook.) Lindb.

Specimens examined: "Russia, the Republic of Tuva, Tes-Khem Distr., East Tannu-Ola Range, Kara-Khol' Lake vicinity, Khol-Oozhu River source, $1740 \mathrm{~m}$. $50^{\circ} 54^{\prime} 27.76^{\prime \prime} \mathrm{N}, 94^{\circ} 19^{\prime} 53.76^{\prime \prime} \mathrm{E}$, on bare peaty soil along a stream on sunny spot in mountain forest-steppe belt. 30 VI 2018. O. Pisarenko. NSK2007307, S+" (NSK, ALTB).

This arctic-alpine species is rare in Russia and occurs mostly in Siberia, both in Arctic and high mountains; it grows usually in moss-lichen and dryad tundra on soil and gravelly substrates. Plagiobryum demissum is reported for Republic of Tuva (Ignatov et al., 2018), but the report is wrong. The report based on a sample of Bardunov from the Kadir-Oruk pass. 19 VII 1961 (IRK, MHA); but in South Siberia there are two passes with the name "Kadir-Oruk" - one is on the Tsagan-Shabit Range in Tuva and another is in the Irkutsk Province in the East Sayan; L.V. Bardunov was collecting in the second locality.

Pseudocalliergon turgescens (T. Jensen) Loeske Specimens examined: "Russia, the Republic of Tuva, Mongun-Taiga Distr., KhindigtikKhol Lake surroundings, 2426 m. $50^{\circ} 22^{\prime} 4.01^{\prime \prime} \mathrm{N}$, $89^{\circ} 58^{\prime} 16.14^{\prime \prime} \mathrm{E}$, big mire massif in the intermountain basin, in moss cover of a hollow. 2 VIII 2019. O. Pisarenko. NSK2007835" (NSK, ALTB); "Russia, the Republic of Tuva, Mongun-Taiga Distr., Chikhacheva Range, N-faced macroslope, ChediTey River headwaters, 2395 m. 50 $10^{\prime} 26.69^{\prime \prime} \mathrm{N}$, $89^{\circ} 25^{\prime} 10.78^{\prime \prime} \mathrm{E}$, sedge-moss swamp on the periphery of small lake. 22 VII 2019. O. Pisarenko. NSK2007829" (NSK); "Russia, the Republic of Tuva, Mongun-Taiga Distr., Mongun-Taiga Mt., S-faced macroslope, interfluve of the Orta-Shegetay and Tolayty rivers, $2850 \mathrm{~m} .50^{\circ} 9^{\prime} 25.6^{\prime \prime} \mathrm{N}$, $90^{\circ} 4^{\prime} 59.63^{\prime \prime} \mathrm{E}$, flat bottom of stream valley, sedge mire. 28 VII 2019. O. Pisarenko. NSK2007864" (NSK); "Russia, the Republic of Tuva, Mongun-Taiga Distr., Tsagan-Shabit Range, S-faced macroslope near Uzun-Khem River, 2470 m. 50²7'33.98"N, 8959'11.72"E, swampy floodplain. 5 VIII 2019. O. Pisarenko. NSK2007863" (NSK); "Russia, the Republic of Tuva, Tes-Khem Distr., East Tannu-Ola Range, Kara-Khol Lake vicinity, S-shore, $1740 \mathrm{~m}$. $50^{\circ} 54^{\prime} 32.04^{\prime \prime} \mathrm{N}, 94^{\circ} 19^{\prime} 44.26^{\prime \prime} \mathrm{E}$, big mire massif. 30 VI 2018. O. Pisarenko. NSK2007358" (NSK); "Russia, the Republic of Tuva, Erzin Distr., San- 
gilen highlands, Naryn River valley vicinity Naryn settlement, $1357 \mathrm{~m} .50^{\circ} 11^{\prime} 46.97^{\prime \prime} \mathrm{N}, 95^{\circ} 38^{\prime} 21.16^{\prime \prime} \mathrm{E}$, floodplain mire with Betula-stand. 08 VII 2013. O. Pisarenko. NSK2007529" (NSK); "Erzin Distr., Sangilen highlands, Naryn Riverheadwaters, $1900 \mathrm{~m}$. $50^{\circ} 13^{\prime} 20.93^{\prime \prime} \mathrm{N}, 96^{\circ} 15^{\prime} 29.88^{\prime \prime} \mathrm{E}$, the bottom of the valley, a spring with a high content of calcium and hydrogen sulfide in water. 11 VII 2013. O. Pisarenko. NSK2004931" (NSK).

Pseudocalliergon turgescens is rather rare arctoalpine species. It is widely distributed in Arctic and Subarctic regions: in Alaska, Canada, Greenland, Scandinavian Mountains; in Russia - from Kola Peninsula to Chukotka, north to Franz Joseph Land and Vrangel Island (Herbarium specimens of Russian mosses. URL: http://arctoa.ru/Flora/basa.php). Farther south it has scattered localities in mountains. In Altai-Sayan region it is known by some samples from Terektinsky and Kurai Ranges in Altai and from Tunkinskiy, Kitoyskiy and Pogranichnyy Ranges in East Sayan (Bardunov, 1974; Ignatov, 1994). There are reports from Mongolian highlands (Tsegmed, 2010). P. turgescens grows in wet habitats - in hollows of mires, near springs and in water of cold lakes. In the Republic of Tuva it is common and dominates in moss cover of highland swamps.

Tayloria lingulata (Dicks.) Lindb.

Specimens examined: "Russia, the Republic of Tuva, Mongun-Taiga Distr., Tsagan-Shabit Range, S-faced macroslope near Uzun-Hem River, elev. $2800 \mathrm{~m}$. $50^{\circ} 28^{\prime} 29.28^{\prime \prime} \mathrm{N}, 90^{\circ} 0^{\prime} 19.8^{\prime \prime} \mathrm{E}$, on peaty soil along a crook 7 VIII 2019. O. Pisarenko. NSK2007819, S+" (NSK, ALTB); "Russia, the Republic of Tuva, Mongun-Taiga Distr., MongunTaiga Mt., N-faced slope to Mugur River tributary, $2250 \mathrm{~m}$. $50^{\circ} 18^{\prime} 59.22^{\prime \prime} \mathrm{N}, 90^{\circ} 14^{\prime} 37.86^{\prime \prime} \mathrm{E}$, wet larchforest, in moss cover in admixture with Campylium stellatum (Hedw.) C. E. O. Jensen. 31 VII 2019. O. Pisarenko. NSK2007820, S+" (NSK).

The species is distributed in the Arctic and Subarctic and in the highlands of the Northern Hemisphere temperate zone. In Russia it occurs sporadically in the tundra zone and highlands from the Caucasus to Sakhalin and Kamchatka (Ignatov et al., 2018). In Altai-Sayan region it is known from the Kantegirsky, Severo-Chuisky and Big Sayan ranges and Kuznetsk Alatau (Bardunov, 1974; Herbarium specimens of Russian mosses. URL: http://arctoa. ru/Flora/basa.php). There are no reports from Mongolia. The species grows usually in relatively wet, swampy habitats, sometimes along streams.

\section{New records for the species previously known by a single specimen}

Fissidens osmundoides Hedw.

Specimens examined: "Russia, the Republic of Tuva, Mongun-Taiga Distr., Chikhacheva Range, $\mathrm{N}$-faced macroslope, Chedi-Tey River headwaters, 2395 m. $50^{\circ} 13^{\prime} 26.69^{\prime \prime} \mathrm{N}, 89^{\circ} 25^{\prime} 10.78^{\prime \prime} \mathrm{E}$, sedgemoss swamp along the periphery of small lake, in admixture with Meesia uliginosa Hedw. 22 VII 2019. O. Pisarenko. NSK2007811" (NSK, ALTB); "Russia, the Republic of Tuva, Mongun-Taiga Distr., Mongun-Taiga Mt, N-faced slope to Mugur River valley, $2914 \mathrm{~m}$. $50^{\circ} 17^{\prime} 52.94^{\prime \prime} \mathrm{N}, 90^{\circ} 12^{\prime} 56.7^{\prime \prime} \mathrm{E}$, goltsy terrace, wet sedge-cobresian tundra, in admixture with Meesia uliginosa. 31 VII 2019. O. Pisarenko. NSK2007828" (NSK). Fissidens osmundoides is widely distributed in the Holarctic, it is found in most parts of the Arctic and boreal zone; further South it grows in the mountains, penetrating to the tropical regions of South- East Asia and the southern States of America; there are reports from the southernmost tip of the South American mainland (Krajewski, 2017). In Altai-Sayan region the species is not rare in Altai and Kuznetsk Alatau (Herbarium specimens of Russian mosses. URL: http://arctoa.ru/Flora/ basa.php); it occurs in Salair and reported for ranges Oyskiy, Kantegirskiy, Yergak-Targak-Tayga in the Western Sayan Mountains and Tunkinskiy Ridge in the Eastern Sayan (Bardunov, 1974). The locality in Yergak-Targak-Tayga Range is specified as "SistigKhem River headwaters" (Bardunov, 1974), so it refers to the Republic of Tuva and located the northeast of the territory. That was the only report of the species for the Republic. There are no records of the species from Mongolia.

Indusiella thianschanica Broth. et Müll. Hal.

Specimens examined: "Russia, the Republic of Tuva, Mongun-Taiga Distr., Tsagan-Shabitu Range, Barlyk River near Aldig-Khem Creek mouth, 2190 m. $50^{\circ} 26^{\prime} 10.43^{\prime \prime} \mathrm{N}, 90^{\circ} 41^{\prime} 57.84^{\prime \prime} \mathrm{E}$, E-aspect steep steppe slope, large vertical outcrops of shale, in fissures, associated with Distichium capillaceum (Hedw.) Bruch et Schimp. 10 VIII 2019. O. Pisarenko. NSK2007832, S+" (NSK, ALTB); "Russia, the Republic of Tuva, Bay-Tayga Distr., Tapsy River valley (Alash river tributary), SE-faced slope, $1420 \mathrm{~m} .5^{\circ} 15^{\prime} 31.18^{\prime \prime} \mathrm{N}, 89^{\circ} 42^{\prime} 28.15^{\prime \prime} \mathrm{E}$, shale outcrops in petrophytic steppe, in fissures. 13 VII 2018. O. Pisarenko. NSK2007308, S+" (NSK). 
Indusiella thianschanica has disjunctive distribution in arid regions of the Northern Hemisphere: in the Pamirs and Tien Shan, in Tibet, in Mongolia and Siberia. Reported from the Caucasus, from Lake Chad in Africa, from Alaska, Bolivia and Argentina. In Siberia the species is very rare and known from scattered localities in Altai-Sayan region, in the Baikal region, in Yakutia and Taimyr. It grows on dry rocks, on the denudated surface of stones and in small crevices. I. thianschanica is in the Red Data Book of the Russian Federation (Dudareva et al., 2008) also in the Red Data Books of number regions of South Siberia including the Republic of Tuva (Pisarenko, Bakalin, 2018). In Tuva for a long time the species was known only by collection of L. V. Bardunov (11 VIII 1968) from Bert-Dag surroundings, East Tannu-Ola Range.

Pseudocalliergon trifarium (F. Weber et D. Mohr) Loeske

Specimens examined: "Russia, the Republic of Tuva, Mongun-Taiga Distr., Chikhacheva Range, $\mathrm{N}$-faced macroslope, Chedi-Tey River headwaters, $2395 \mathrm{~m} . \quad 50^{\circ} 13^{\prime} 26.69^{\prime \prime} \mathrm{N}, 8^{\circ} 25^{\prime} 10.78^{\prime \prime} \mathrm{E}$, sedge-moss swamp along the periphery of small lake. 22 VII 2019. O. Pisarenko. NSK2007839" (NSK, ALTB); "Russia, the Republic of Tuva, Bay-Tayga Distr., Kara-Khol` Lake vicinity, CasteKhol River headwaters, 1927 m. $51^{\circ} 25^{\prime} 21.68^{\prime \prime} \mathrm{N}$, $89^{\circ} 24^{\prime} 27.11^{\prime \prime} \mathrm{E}$, big mire massif in the intermountain basin, in moss cover in admixture with Scorpidium revolvens (Sw. ex anon.) Rubers and Sphagnum platyphyllum (Lindb. ex Braithw.) Warnst. 11 VII
2018. O. Pisarenko. NSK2007517" (NSK); "Russia, the Republic of Tuva, Mongun-Taiga Distr., Mongun-Taiga Mt., S-faced macroslope, interfluve of the Orta-Shegetay and Tolayty rivers, $2850 \mathrm{~m}$. $50^{\circ} 9^{\prime} 25.6^{\prime \prime} \mathrm{N}, 90^{\circ} 4^{\prime} 59.63^{\prime \prime} \mathrm{E}$, flat bottom of stream valley, sedge mire, in moss cover in admixture with Warnstorfia sarmentosa. 28 VII 2019. O. Pisarenko. NSK2007861" (NSK).

Pseudocalliergon trifarium is distributed in the Holarctic, mainly in the northern regions and in the highlands. It grows in swamps rich in mineral nutrition, often in places of groundwater outlets with a high content of carbonates. In Siberia it is rare. In the West Siberian plain it penetrates south to the southern part of the Great Vasyugan mire; in AltaiSayan region it is known from a few scattered localities in Altai, Kuznetsk Alatau and Salair (Ignatov, 1994; Pisarenko, 2014). In Republic of Tuva the species first time was recently reported from Sangilen (Pisarenko, 2013); according to new data it is rather constant component of moss cover in Tuva highland mires.

Newly revealed species are different in ecology and area; they belong to different geographical elements. That confirms the thesis of bryological knowledge deficiency for the Republic of Tuva and the need to continue research.

\section{Acknowledgements}

The work is funded by RFBR № 18-04-00822; samples replenished bio-collection according to USU 440537.

\section{REFERENCES / ЛИTEPATУPA}

Abramova A. L., Tsegmed Ts. 1983. Rare and interesting species of Mongolia. Novosti sistematiki nizshikh rasteniy [Novit. Syst. Pl. non Vasc.] 20: 173-179. [In Russian] (Абрамова А. Л., Цэгмэд Ц. Редкие и интересные виды Монголии // Новости сист. низш. раст., 1983. Т. 20. С. 173-179).

Bardunov L. V. 1972. Rare and interesting species in the moss flora of the Tuva Republic and southern part of the Krasnoyarsk territory. Izvestiya Sibirskogo otdeleniya Akademii nauk SSSR, seriya biologicheskaya [Proceedings of the Siberian Branch of Russian Academy of Sciences. Biology] 2, 5: 139-141. [In Russian] (Бардунов Л. В. Редкие и интересные виды во флоре мхов Тувинской АССР и южной части Красноярского края // Изв. Сиб. отд. АН СССР. Сер. биол., 1972. Вып. 2, № 5. С. 139-141).

Bardunov L. V. 1974. Listostebelnyye mkhi Altaya i Sayan [Mosses of Altai and Sayan]. Novosibirsk: Nauka. 168 pp. [In Russian] (Бардунов Л. В. Листостебельные мхи Алтая и Саян. Новосибирск: Наука, 1974. 168 с.).

Bardunov L. V. 2008. Aongstroemia julacea (Hook.) Mitt. In.: Krasnaya kniga Rossiyskoy Federatsii (rasteniya $i$ griby) [Red Data Book of the Russian Federation (plants and fungi)]. Moscow: KMK Scientific Press Ltd. P. 614. [In Russian] (Бардунов Л. В. Онгстремия сережчатая - Aongstroemia julacea (Hook.) Mitt. // Красная книга Российской Федерации (растения и грибы). М.: Товарищество научных изданий КМК, 2008. С. 614).

Czernyadjeva I. V., Ignatova E. A., Kharzinov Z. Kh. 2008. Hilpertia velenovskyi (Schiffn.) R. H. Zander. In: Krasnaya kniga Rossiyskoy Federatsii (rasteniya i griby) [Red Data Book of the Russian Federation (plants and fungi)]. Moscow: KMK Scientific Press Ltd. Pp. 629-630. [In Russian] (Чернядьева И. В., Игнатова Е. А., Харзинов 3. Х. Хилпертия Веленовского - Hilpertia velenovskyi (Schiffn.) R. H. Zander. // Красная книга Российской Федерации (растения и грибы). М.: Товарищество научных изданий КМК, 2008. С. 639-630). 
Dudareva N. V., Tubanova D. Ya., Ivanova E. I. 2008. Indusiella thianschanica Broth. et Müll. Hal. In.: Krasnaya kniga Rossiyskoy Federatsii (rasteniya i griby) [Red Data Book of the Russian Federation (plants and fungi)] Moscow: KMK Scientific Press Ltd. P. 617. [In Russian]. (Дударева Н. В., Тубанова Д. Я., Иванова Е. И. Индузиэлла тяньшанская - Indusiella thianschanica Broth. et Müll. Hal. // Красная книга Российской Федерации (растения и грибы). М.: Товарищество научных изданий КМК, 2008. С. 617).

Herbarium specimens of Russian mosses. In: Arctoa: a Journal of Bryology. URL: http://arctoa.ru/Flora/basa.php (Accessed 20 March 2020).

Hodgetts N. G. 2015. Checklist and country status of European bryophytes - towards a new Red List for Europe. Irish Wildlife Manuals 84: 1-125.

Ignatov M. S. 1994. Bryophytes of Altai mountains. I. Study area and history of its bryological explorations. Arctoa 3: 13-27.

Ignatov M. S., Afonina O. M., Ignatova E. A., Abolina A., Akatova T. V., Baisheva E. Z., Bardunov L. V., Baryakina E. A., Belkina O. A., Bezgodov A. G., Boychuk M. A., Cherdantseva V. Ya., Czernyadjeva I. V., Doroshina G. Ya., Dyachenko A. P., Fedosov V. E., Goldberg I. L., Ivanova E. I., Jukoniene I., Kannukene L., Kazanovsky S. G., Kharzinov Z. Kh., Kurbatova L. E., Maksimov A. I., Mamatkulov U. K., Manakyan V. A., Maslovsky O. M., Napreenko M. G., Otnyukova T. N., Partyka L. Ya., ;lk O. Yu., Popova N. N., Rykovsky G. F., Tubanova D. Ya., Zheleznova G. V., Zolotov V. I. 2006. Check-list of mosses of East Europe and North Asia. Arctoa 15: 1-130. DOI: 10.15298/arctoa.15.01

Ignatov M. S., Ignatova E. A. 2004. Moss flora of the Middle European Russia. Vol. 2: Fontinalaceae-Amblystegieceae. Moscow: KMK Scientific Press Ltd. Pp. 609-944. [In Russian] (Игнатов М. С., Игнатова Е. А. Флора мхов средней части Европейской России. Т. 2. Fontinalaceae - Amblystegiaceae. М.: Товарищество научных изданий КМК, 2004. С. 609-944).

Ignatov M. S., Ignatova E. A., Fedosov V. E., Ivanova E. I., Blom H. H., Muñoz J., Bednarek-Ochyra H., Afonina O. M., Kurbatova L. E., Czernyadjeva I. V., Cherdantseva V. Ya. 2017. Moss flora of Russia. Vol. 2. Oedipodiales - Grimmiales. Ed. M. S. Ignatov. Moscow: KMK Scientific Press Ltd. 560 pp.

Ignatov M. S., Ignatova E. A., Fedosov V. E., Zolotov V. I., Koponen T., Czernyadjeva I. V., Doroshina G. Y., Tubanova D. Y., Bell N. E. 2018. Moss flora of Russia. Vol. 4. Bartramiales - Aulacomniales. Ed. M. S. Ignatov. Moscow: KMK Scientific Press Ltd. 543 pp.

Konspekt flory Aziatskoy Rossii: Sosudistyye rasteniya [Check-list of the flora of Asian Russia: Vascular plants]. 2012. Novosibirsk: Izdatelstvo SO RAN. 640 pp. [In Russian] (Конспект флоры Азиатской России: Сосудистые растения. Новосибирск: Изд-во СО РАН, 2012. 640 с.).

Krajewski L. 2017. Drepanocladus turgescens (Bryophyta, Amblystegiaceae) rediscovered in Poland. Cryptogamie, Bryologie 38(3): 265-273.

Lapshina E. D. 2003. Flora bolot yugo-vostoka Zapadnoy Sibiri [Flora of mires of southeastern part of West Siberia]. Tomsk: Tomsk State University Publishers. 296 pp. [In Russian] (Лапшина Е. Д. Флора болот юго-востока Западной Сибири. Томск: Изд-во Томского ун-та, 2003. 296 с.).

Otnyukova T. N. 2003. Contribution to the moss flora of Todzha Valley (Tyva Republic, South Siberia). Arctoa 12: 97-109. [In Russian] (Отнюкова T. Н. Материалы к флоре листостебельных мхов Тоджинской котловины (Республика Тува, Южная Сибирь) // Arctoa, 2003. Т. 12. С. 97-109).

Pisarenko O. Yu. 2013. New moss records from Tyva Republic. 1. Arctoa 22: 253-254.

Pisarenko O. Yu. 2014. Mosses of Salair-Kuznetsk region (Altai-Sayan mountain country) and adjacent plains of West Siberia. Arctoa 23: 33-58. DOI: 10.15298/arctoa.23.06

Pisarenko O. Yu. 2018. New moss records from Tyva Repablic. 2. Arctoa 27, 2: 219-221. DOI: 10.15298/ arctoa.27.19

Pisarenko O. Yu., Artemov I. A. 2019. On the bryophyte flora of the Sengilen Range. Problems of Botany of South Siberia and Mongolia 18: 365-368. [In Russian] (Писаренко О. Ю., Артемов И. А. К флоре мхов хребта Сенгилен // Проблемы ботаники Южной Сибири и Монголии, 2019. Вып. 18. С. 365-368). DOI: 10.14258/ pbssm.2019073

Pisarenko O. Yu., Bakalin V. A. 2018. Bryophytes. In: Krasnaya kniga Respubliki Tyva (zhivotnyye, rasteniya $i$ griby) [Red Data Book of the Republic of Tuva: animals, plants and mushrooms]. Kyzyl: Favorit. Pp. 415-432. [In Russian] (Писаренко О. Ю., Бакалин В. А. Моховидные // Красная книга Республики Тыва: животные, растения и грибы. Кызыл: Фаворит, 2018. С. 415-432).

Takhtajan A. L. 1986. Floristic regions of the world. Berkeley: University of California Press. 522 pp.

Tsegmed T. 2010. Moss flora of Mongolia. In: Biologicheskiye resursy i prirodnyye usloviya Mongolii: Trudy sovmestnoy Rossiysko-Mongolskoy kompleksnoy biologicheskoy ekspeditsii [Biological resources and environmental conditions of Mongolia: works of joint Russian and Mongolian complex biological expedition]. Vol/ 56. Moscow: Institut Problem ekologii i evolutsii im. A. N. Severtsova RAN. Pp. 1-634. [In Russian] (Цэгмэд Ц. Флора мхов Монголии // Биологические ресурсы и природные условия Монголии: Труды совместной Российско-Монгольской комплексной биологической экспедиции. Т. 56. М.: Институт экологии и эволюции им. А. Н. Северцева PAH, 2010. С. 10-634). 